\title{
Atividade antibacteriana in vitro de inflorescências de Achyrocline satureioides (Lam.) DC. - Asteraceae ("macela", "marcela") sobre agentes bacterianos de interesse em alimentos
}

\author{
MOTA, F.M. ${ }^{1}$; CARVALHO, H.H.C. ${ }^{2}$; WIEST, J.M. ${ }^{1,2 *}$ \\ ${ }^{1}$ Programa de Pós-Graduação em Ciências Veterinárias da Universidade Federal do Rio Grande do Sul, Av. Bento \\ Gonçalves, 9090, CEP: 91501-970, Porto Alegre-Brasil 2Instituto de Ciência e Tecnologia de Alimentos da \\ Universidade Federal do Rio Grande do Sul, Av. Bento Gonçalves, 9.500, Caixa Postal 15090, CEP: 91501-970, \\ Porto Alegre-Brasil *00002497@ufrgs.br
}

RESUMO: Através de Testes de diluição em sistema de tubos múltiplos determinou-se in vitro, atividade antibacteriana em inflorescências de Achyrocline satureioides (Lam.) DC. - Asteraceae ("macela", "marcela"), expressa como Intensidade de Atividade de Inibição Bacteriana (IINIB/ bacteriostasia) e Intensidade de Atividade de Inativação Bacteriana (IINAB/bactericidia), a partir de formas de extração etanólica (hidroalcoolaturas) e hídrica (decoctos), sobre inóculos padronizados de Enterococcus faecalis (ATCC 19433), Staphylococcus aureus (ATCC 25923), Escherichia coli (ATCC 11229) e Salmonella enteritidis (ATCC 11076). E. faecalis apresentou a maior sensibilidade, seguido por Staphylococcus aureus, enquanto $S$. enteritidis e E. coli apresentaram-se mais resistentes. Dentre as formas de extração, a hidroalcoolatura apresentou capacidade de inibição e/ou inativação intensa e seletiva frente aos quatro inóculos bacterianos. Os decoctos mostraram-se completamente ineficazes frente às bactérias Gram-negativas, enquanto que as Gram-positivas apresentaram somente bacteriostasia/inibição.

Palavras-chave: Achyrocline satureioides, atividade antibacteriana, inibição bacteriana, inativação bacteriana

\begin{abstract}
In vitro antibacterial activity of inflorescences of Achyroclines satureioides (Lam.) DC. - Asteraceae ("macela", "marcela") on bacterial agents of interest in food. Dilution test in multiple tube system was used to determine the in vitro antibacterial activity in inflorescences of Achyrocline satureioides (Lam.) DC. - Asteraceae ("macela", "marcela"), expressed as intensity of bacterial inhibition activity (IINIB/bacteriostasis) and intensity of bacterial inactivation activity (IINAB/bactericidie), from ethanol (hydroalcoholic) and water (decoction) extraction forms on standardized inocula of Enterococcus faecalis (ATCC 19433), Staphylococcus aureus (ATCC 25923), Escherichia coli (ATCC 11229) and Salmonella enteritidis (ATCC 11076). $E$. faecalis had the highest sensitivity, followed by $S$. aureus, while $S$. enteritidis and E. coli were more resistant. Of the extraction forms, the hydroalcoholic one showed intense and selective inhibition and/or inactivation capacity against four bacterial inocula. Decoctions were completely ineffective against the Gram-negative bacteria, whereas Gram-positive bacteria showed only bacteriostasis/inhibition.
\end{abstract}

Key words: Achyrocline satureioides, antibacterial activity, bacterial inhibition, bacterial inactivation

\section{INTRODUÇÃO}

O emprego de plantas medicinais na recuperação da saúde tem evoluído ao longo dos tempos, desde as formas mais simples de tratamento tópico até as formas tecnologicamente sofisticadas da fabricação industrial (Lorenzi \& Matos, 2008).
Atualmente está ressurgindo o interesse pelo uso na terapêutica, por diversos motivos, dentre eles as contra-indicações, os efeitos colaterais e os prejuízos causados pelo uso abusivo e/ou incorreto de medicamentos sintéticos, o fato de que amplas

Recebido para publicação em 19/08/2009

Aceito para publicação em 09/02/2011

Rev. Bras. PI. Med., Botucatu, v.13, n.3, p.298-304, 2011. 
camadas da população mundial não têm acesso aos medicamentos e a crença popular de que o natural é inofensivo (Rates, 2001).

Considerando as inúmeras transformações decorrentes da evolução humana, destacando, consequentemente, a degradação ambiental com a escassez de recursos naturais, Schenkel et al. (2003) afirmam que as plantas medicinais e os extratos hoje representam uma das alternativas entre as diversas fontes de insumos necessários à existência da sociedade, tendo como principal vantagem o fato de ser fonte renovável e, em grande parte, controlável pelo gênero humano.

Achyrocline satureioides (Lam.) DC. é uma planta pertencente à família Asteraceae, popularmente denominada "marcela" ou mesmo "macela". Lorenzi \& Matos (2008) relatam que Achyroclines satureioides apresenta cientificamente sinônimos como Achyrocline candicans (Kunth) DC., Achyrocline flaccida DC., Gnaphalium satureioides Lam., Gnaphalium candicans Kunth, sendo conhecida também pelos nomes comuns de "macela", "alecrimde-parede", "camomila-nacional", "macela-amarela", "macela-da-terra", "macela-do-campo", "macela-dosertão", "macelinha", "marcela", "marcela-do-campo", dentre outros. Segundo Simões et al. (1988) nos países vizinhos ao nosso é conhecida por "macela galega", "marcella hembra", "marcelita" e "yatei-caá" (em Tupi-guarani).

Para Calvo et al. (2006), Achyrocline satureioides (Lam.) DC. é subarbusto originário da América e distribuído na Europa e África. É usualmente usado em infusões como digestivo, antiespasmódico, tendo também atividade antimicrobiana e antiviral.

$\mathrm{Na}$ epidemiologia e profilaxia de doenças transmissíveis, a pesquisa de fatores de proteção sustentáveis, alternativos, dirigida a recursos naturais renováveis como plantas com indicativo medicinal, condimentar ou aromático constitui prioridade pela Organização Mundial de Saúde, com ênfase aos aspectos culturais e tradicionais envolvidos e a relação com a atenção básica em saúde coletiva, em alimentos/alimentação, e em saúde e produção animal (Wiest et al., 2009a). Em vista disto, a marcela tem sido citada em pesquisas de resgate etnográfico como efetiva planta medicinal, sendo as inflorescências utilizadas como infusos (chás) para efeitos antidiarreicos, antiespasmódicos, analgésico, antiinflamatória e antimicrobiana (Boscolo \& Valle, 2008) e também confirmadas a atividade farmacológica (Vendruscolo et al., 2005). Além disso, Zayachkivska et al. (2005) relacionam estes efeitos ao conteúdo de flavonóides presentes em alta concentração na marcela, afirmando inclusive que a forma de extração destes princípios bioativos influenciam na atividade biológica.
Tendo em vista o estudo com base no uso popular, torna-se interessante a realização de testes com extratos brutos, pois pesquisas demonstram que quando uma planta possui determinada atividade, não necessariamente está relacionada a um único composto ativo (Phillipson, 2003).

No Brasil, a pesquisa da atividade antimicrobiana em plantas com indicativo medicinal, condimentar ou aromático vem merecendo destaque como demonstram os trabalhos desenvolvidos por Lemos et al. (2000) e Avancini \& Wiest (2008) que pesquisaram especificamente a atividade bactericida de macela relacionadas a mastite bovina, bem como, nos trabalhos de triagem antibacteriana contra agentes de interesse em toxinfecções alimentares, onde a referida planta apresentou resultados interessantes no controle bactericida/ bacteriostático contra padrões ATCC de Salmonella sp. (Wiest et al., 2009a), Escherichia coli (Wiest et al., 2009b) e Sthaphylococcus aureus (Wiest et al., 2009c).

Considerando a utilização medicinal da marcela pela população do Rio Grande do Sul e os diferentes estudos científicos da ação biológica desta planta, o presente trabalho se propõe determinar a atividade antibacteriana in vitro de extratos etanólicos (hidroalcoolaturas seguidas da evaporação do etanol em sistema de rota-vapor e posterior reconstituição hídrica sob assepsia) e de extrato hídrico (decoctos com e sem reconstituição hídrica posterior) em inflorescências de Achyrocline satureioides (Lam.) DC. - Asteraceae "macela", "marcela"), expressa como IINIB (Intensidade de Atividade de Inibição Bacteriana/ bacteriostasia) e IINAB (Intensidade de Atividade de Inativação Bacteriana/bactericidia) sobre bactérias de interesse em alimentos como Enterococcus faecalis (ATCC 19433), Staphylococcus aureus (ATCC 25923), Escherichia coli (ATCC 11229) e Salmonella Enteritidis (ATCC 11076). Sintetizando, manipulam-se as variáveis bactérias Gram-negativas e positivas, as formas de extração, os tempos de confrontação e a presença ou ausência de desinibidores bacterianos, permanecendo constante a concentração final das diferentes formas de extração.

\section{MATERIAL E MÉTODO}

No presente trabalho foram utilizadas inflorescências desidratadas de Achyrocline satureioides, adquiridas de uma empresa do ramo fitoterápico localizada na região metropolitana de Porto Alegre/RS. Este material, sob a forma de exsicatas segundo Ming (1996), foi identificado, caracterizado e certificado botanicamente pela bióloga Silvia Maria Marodin (CRBioRS - 17268) a partir de literatura taxionômica e de confrontações com exsicatas anteriormente depositadas no Herbário do Instituto de Biociências/Departamento de Botânica 
da Universidade Federal do Rio Grande do Sul, Porto Alegre/RS, Brasil.

As inflorescências da planta foram submetidas a três formas de extração, sendo uma por extração hidroalcoólica e as outras duas por decocção (com e sem reconstituição hídrica posterior) conforme estabelecido pela Farmacopéia Brasileira (1987). Para a obtenção do extrato hidroalcoólico partiu-se de álcool etílico de cereais à 75GL, na proporção de $100 \mathrm{~g}$ de planta seca para $1000 \mathrm{~mL}$ de álcool. Após 15 dias, este extrato foi submetido à destilação fracionada sob pressão reduzida em sistema rota-vapor (FISOTAN®), desprezando-se a porção alcoólica com posterior reidratação asséptica do concentrado final, reestabelecendo-se assim as concentrações iniciais da planta seca no extrato vegetal. Para obtenção dos extratos aquosos ou decoctos, as inflorescências secas na proporção de $100 \mathrm{~g}$ de planta para $1000 \mathrm{~mL}$ de água destilada estéril, foram deixadas em ebulição por quinze minutos em aquecedor de refluxo, com reconstituição ou não do volume evaporado através de água destilada estéril. Os extratos brutos obtidos foram chamados de extrato hidroalcoólico reconstituido, decocto com reconstituição e decocto sem reconstituição, respectivamente.

Foram desafiadas quatro linhagens bacterianas padrão ATCC (American Type Culture Collection), duas Gram-negativas: Salmonella Enteritidis (ATCC 13076) e Escherichia coli (ATCC 11229) e duas Gram-positivas: Staphylococcus aureus (ATCC 25923) e Enterococcus faecalis (ATCC 19433), provenientes da coleção - bacterioteca do Laboratório de Higiene do Instituto de Ciências e Tecnologia dos Alimentos/UFRGS, mantidas em meio nutriente (NutrientAgar, OXOID e BHI-Agar, OXOID), reativadas em infusão de cérebro e coração (BHI, OXOID) à 36드 por 18 a 24 horas de incubação aeróbia. A avaliação da concentração inicial foi realizada através da técnica de microgota (Romeiro, 2008), a contagem de microrganismos viáveis foi concretizada em placas de Petri contendo meio de cultura PCA (Plate Count Agar, HIMEDIA) e o valor final considerado constitui-se da média das contagens das gotas triplicadas avaliadas biometricamente, segundo Cavalli-Sforza (1974).

Para a avaliação da atividade antibacteriana dos diferentes extratos estudados, lida como IINIB e IINAB, utilizaram-se os testes de diluição (DVG, 1981), com base na Técnica do sistema de tubos múltiplos referida por Souza \& Wiest (2007), Avancini \& Wiest (2008) e Carvalho et al. (2010), confrontando os extratos brutos na concentração de $50 \%$ das diferentes formas de extração com diluições seriais logarítmicas $\left(10^{-1}\right.$ a $10^{-9}$ UFC $\left.\mathrm{mL}^{-1}\right)$ das bactérias padrões em teste, controlando o crescimento bacteriano por plaqueamento específico, bem como prováveis contaminações intervenientes.

Entende-se por IINIB (bacteriostasia), o resultado do confronto das bactérias com os extratos antibacterianos de marcela em meio BHI AGAR (DIFCO), e por IINAB (bactericidia) o mesmo resultado, porém sob a influência de desinibidores (ou desestressantes) bacterianos como o Tween 80, histidina e lecitina acrescidos ao meio específico (WU, 2008). Estes valores são representações da atividade biológica inibitória/bacteriostática ou inativadora/ bactericida dos extratos de marcela sobre os microrganismos. Desta forma atribuiu-se, para fins estatísticos, o valor máximo 11 (onze) quando a atividade de inibição ou de inativação da concentração determinada do extrato vegetal correspondeu à inibição ou inativação de $10^{-1}$ ou $10^{8} \mathrm{UFC} \mathrm{mL} \mathrm{mL}^{-1}$, ou o valor 2 (dois) quando da verificação de nenhuma atividade (Tabela 1).

A avaliação dos resultados obtidos das variáveis de IINIB e de IINAB para as diferentes formas de extração de marcela confrontadas in vitro com os agentes bacterianos foi verificada através da análise de variância (ANOVA), com complementação pelo Teste de Tukey, segundo o programa SISVAR5.0 (2007).

TABELA 1. Representação dos valores ordinais arbitrários de intensidade de atividade atribuídos às variáveis Intensidade da Atividade de Inibição Bacteriana/bacteriostasia (IINIB) e de Intensidade de Atividade de Inativação Bacteriana/bactericidia (IINAB) e suas correspondentes diluições e doses infectantes dos inóculos.

\begin{tabular}{ccccccccccc}
\hline 11 & 10 & 9 & 8 & 7 & 6 & 5 & 4 & 3 & 2 & $\begin{array}{l}\text { Variáveis ordinais de } \\
\text { intensidade de atividade }\end{array}$ \\
\hline $10^{-1}$ & $10^{-2}$ & $10^{-3}$ & $10^{-4}$ & $10^{-5}$ & $10^{-6}$ & $10^{-7}$ & $10^{-8}$ & $10^{-9}$ & $\begin{array}{l}\text { UFC mL } \mathrm{mL}^{-1} \text { diluições dos } \\
\text { inóculos inibidas ou } \\
\text { inativadas }\end{array}$ \\
$10^{8}$ & $10^{7}$ & $10^{6}$ & $10^{5}$ & $10^{4}$ & $10^{3}$ & $10^{2}$ & $10^{1}$ & 1 & $\begin{array}{c}\text { U.a. } \\
\text { UFC mL } \mathrm{m}^{-1} \text { - doses } \\
\text { infectantes inibidas ou } \\
\text { inativadas }\end{array}$ \\
\hline
\end{tabular}

n.a = ausência de atividade antibacteriana; UFC mL $\mathrm{m}^{-1}=$ Unidades Formadoras de Colônias por mililitro 


\section{RESULTADO E DISCUSSÃO}

Os resultados completos da atividade antibacteriana das três formas de extração de Achyrocline satureioides (Lam.) DC. - Asteraceae ("macela", "marcela"), expressa como Intensidade de Atividade de Inibição Bacteriana (IINIB/bacteriostasia) e Intensidade de Atividade de Inativação Bacteriana (IINAB/bactericidia), considerando as variáveis tempo, forma de extração e presença ou ausência de desinibidores bacterianos, confrontadas com quatro diferentes espécies de bactérias de interesse alimentar, encontram-se expostos na Tabela 2. Chama-se a atenção que os valores mais altos significam atividade antibacteriana também alta e o valor 2 significa atividade antibacteriana ausente. Como em relação ao tempo de exposição não houve nas 144 horas em que os diferentes extratos ficaram em contato com as várias concentrações dos inóculos, diferenças significativas em relação aos resultados encontrados, esta variável (tempo de exposição) foi considerada independente para os demais cálculos estatísticos.

Quando avaliada a sensibilidade das quatro espécies bacterianas padrões frente aos diferentes extratos de marcela, independente das demais variáveis manipuladas, houve diferença significativa entre as bactérias como mostra a Tabela 3. Nota-se que as bactérias gram-positivas (estafilococos e enterococos) foram mais sensíveis aos extratos do que as bactérias Gram-negativas (salmonela e escherichia). Sendo que o inóculo padrão mais sensível foi $S$. aureus. Estes resultados confirmam o trabalho de Calvo et al. (2006) confrontando extratos de marcela a diferentes cepas de Staphylococcus aureus isolados de casos clínicos.

Ao se avaliar as duas variáveis, ausência de desinibidores (IINIB/bacteriostasia) e presença de desinibidores (IINAB/bactericidia), independente das outras variáveis manipuladas, observou-se diferenças significativas como mostra a Tabela 4. A adição dos desinibidores como fator desestressante para bactérias é referenciada por Wu (2008), pois bactérias estressadas têm a capacidade de se recuperar e retornar ao estado fisiológico normal sob condições favoráveis. O tratamento IINIB (bacteriostasia/inibição pela ausência de desinibidores) apresentou resultados superiores ao de IINAB (bactericidia/inativação pela presença de desinibidores). Esta ação bacteriostática dos extratos de marcela quando da adição dos desinibidores ou desestressantes ao meio específico também é demonstrada nos trabalhos de Carvalho et al. (2005), Souza \& Wiest (2007) e Girolometto (2009)

TABELA2. Intensidade de Atividade de Inibição Bacteriana (IINIB/bacteriostasia) e Intensidade de Atividade de Inativação Bacteriana (IINAB/bactericidia) produzida por diferentes formas de extração de inflorescências de Achyrocline satureioides (Lam.) DC. ("marcela", "macela"), na concentração de $50 \%$, sobre inóculos bacterianos padrões, em até 144 horas de incubação aeróbia à $37^{\circ} \mathrm{C}$, expressas em valores ordinais arbitrários.

\begin{tabular}{lccccccccc}
\hline \multirow{2}{*}{$\begin{array}{c}\text { Foma de } \\
\text { Extração }\end{array}$} & $\begin{array}{c}\text { Tempo } \\
\text { (h) }\end{array}$ & $\begin{array}{c}\text { Staphylococcus } \\
\text { aureus }\end{array}$ & $\begin{array}{c}\text { Enterococcus } \\
\text { faecalis }\end{array}$ & $\begin{array}{c}\text { Sallmonella } \\
\text { enteritidis }\end{array}$ & $\begin{array}{c}\text { Escherichia } \\
\text { coli }\end{array}$ \\
\cline { 3 - 10 } & 24 & 10,33 & 8,00 & 10,33 & 10,33 & 11,00 & 9,67 & 10,00 & 10,00 \\
& IINIB & INNAB & IINIB & IINAB & IINIB & IINAB & IINIB & IINAB \\
\hline \multirow{2}{*}{ Hidroalcoolatura } & 48 & 10,33 & 8,67 & 10,33 & 10,33 & 11,00 & 11,00 & 10,00 & 10,00 \\
& 72 & 10,33 & 9,33 & 10,33 & 10,33 & 11,00 & 11,00 & 10,00 & 10,00 \\
& 144 & 10,33 & 9,33 & 10,33 & 10,33 & 11,00 & 11,00 & 10,00 & 10,00 \\
\hline Decocto com & 24 & 5,00 & 2,00 & 10,00 & 2,00 & 2,00 & 2,00 & 2,00 & 2,00 \\
reconstituição & 48 & 5,00 & 2,00 & 10,00 & 2,00 & 2,00 & 2,00 & 2,00 & 2,00 \\
& 72 & 6,00 & 2,00 & 10,00 & 2,00 & 2,00 & 2,00 & 2,00 & 2,00 \\
& 144 & 7,00 & 2,00 & 10,00 & 2,00 & 2,00 & 2,00 & 2,00 & 2,00 \\
\hline Decocto sem & 24 & 8,00 & 2,00 & 10,00 & 2,00 & 2,00 & 2,00 & 2,00 & 2,00 \\
reconstituição & 48 & 9,00 & 2,00 & 10,00 & 2,00 & 2,00 & 2,00 & 2,00 & 2,00 \\
& 72 & 9,00 & 2,00 & 10,00 & 2,00 & 2,00 & 2,00 & 2,00 & 2,00 \\
& 144 & 10,00 & 2,00 & 10,00 & 2,00 & 2,00 & 2,00 & 2,00 & 2,00 \\
\hline
\end{tabular}

IINIB = sem desinibidor/bacteriostasia

IINAB = com desinibidor/bactericidia Obs: os valores arbitrários expressam as médias de três repetições indepedentes

Rev. Bras. PI. Med., Botucatu, v.13, n.3, p.298-304, 2011. 
testando outras plantas e aplicando a mesma metodologia.

Ao se avaliar as duas variáveis, ausência de desinibidores (IINIB/bacteriostasia) e presença de desinibidores (IINAB/bactericidia), independente das outras variáveis manipuladas, observou-se diferenças significativas como mostra a Tabela 4. A adição dos desinibidores como fator desestressante para bactérias é referenciada por Wu (2008), pois bactérias estressadas têm a capacidade de se recuperar e retornar ao estado fisiológico normal sob condições favoráveis. O tratamento IINIB (bacteriostasia/inibição pela ausência de desinibidores) apresentou resultados superiores ao de IINAB (bactericidia/inativação pela presença de desinibidores). Esta ação bacteriostática dos extratos de marcela quando da adição dos desinibidores ou desestressantes ao meio específico também é demonstrada nos trabalhos de Carvalho et al. (2005), Souza (2007) e Girolometto (2009) testando outras plantas e aplicando a mesma metodologia.

A Tabela 5 avalia a atividade antibacteriana dos extratos de marcela obtidos a partir de diferentes métodos de extração sobre as principais bactérias causadoras de toxinfecções alimentares. Dentre estas, $S$. aureus apresentou diferença significativa em todos os tipos de extração, sendo a forma de extração hidroalcoólica aquela que apresenta maior ação sobre a referida bactéria, seguido da extração por decocto sem reconstituição e finalmente pelo decocto com reconstituição. Para salmonela e escherichia, somente a extração por hidroalcoolatura foi efetiva, enquanto que as duas formas de decocção não apresentaram atividade alguma (valor $2 / \mathrm{sem}$ atividade). Já a espécie $E$. faecalis apresentou sensibilidade a todas as formas de extração, sendo que a melhor foi também a hidroalcoólica.

Quando avaliados os três métodos de extração, verifica-se que a extração hidroalcoólica apresenta valores superiores em relação as outras duas. Vários trabalhos já mencionados (Souza \& Wiest, 2007; Girolometto, 2009; Wiest et al., 2009a; 2009b; 2009c) testando várias plantas, incluindo a marcela, com a mesma metodologia, também obtiveram resultados superiores para a forma de extração hidroalcoólica e inferiores para o decocto. Uma hipótese para estas diferenças também caracterizadas por Passos (2009) pode estar relacionada à perda de óleos essenciais voláteis, que na extração por decocção está associada à utilização de temperaturas elevadas (ebulição) em comparação

TABELA 3. Avaliação da sensibilidade dos quatro diferentes inóculos bacterianos padrões frente aos extratos de Achyrocline satureioides (Lam.) DC. ("marcela", "macela"), na concentração de $50 \%$, independente das variáveis tipo de extração, tempo de confrontação e presença ou ausência de desinibidores bacterianos, expressas em valores ordinais arbitrários.

\begin{tabular}{cc}
\hline Espécies bacterianas ATCC & $\begin{array}{c}\text { Atividade antibacteriana - } \\
\text { extratos } \\
\text { (valores arbitrátrários) }\end{array}$ \\
\hline Staphylococcus aureus & $6,31^{\mathrm{a}}$ \\
Enterococcus faecalis & $7,44^{\circ}$ \\
Salmonella enteritidis & $4,88^{\circ}$ \\
Escherichia coli & $4,66^{\circ}$ \\
\hline
\end{tabular}

Letras minúsculas diferentes sobrescritas ( $\left.{ }^{\underline{a}}\right)$ na mesma coluna indicam diferenças significativas entre as espécies bacterianas para a análise de variância (Anova) e teste de Tukey $(p<0,05)$.

TABELA4. Avaliação da ausência (IINAB) e da presença (IINIB) de desinibidores bacterianos (Tween 80, histidina e lecitina) na atividade antibacteriana de extratos de Achyrocline satureioides (Lam.) DC. ("macela"), na concentração de 50\%, independente das variáveis tempo de confrontação, tipo de extração e espécie bacteriana.

\begin{tabular}{cc}
\hline $\begin{array}{c}\text { Presença ou ausência de desinibidores } \\
\text { bacterianos }\end{array}$ & $\begin{array}{c}\text { Atividade antibacteriana - extratos } \\
\text { (valores arbitrátrários) }\end{array}$ \\
\hline IINAB (bactericidia/presença de desinibidores) & $4,64^{\mathrm{a}}$ \\
IINIB (bacteriostasia/ausência de desinibidores) & $7,02^{\mathrm{b}}$ \\
\hline
\end{tabular}

Letras minúsculas diferentes sobrescritas ( $\underline{a}$ ) na mesma coluna indicam diferenças significativas entre as espécies bacterianas para a análise de variância (Anova) e teste de Tukey $(p<0,05)$.

Rev. Bras. PI. Med., Botucatu, v.13, n.3, p.298-304, 2011. 
TABELA 5. Avaliação da relação da atividade antibacteriana entre os inóculos bacterianos padrões e os diferentes tipos de extração de Achyrocline satureioides (Lam.) DC. (“macela”), na concentração de 50\%, independente dos fatores tempo de confrontação, presença ou ausência de desinibidores bacterianos, expressas em valores ordinais arbitrários.

\begin{tabular}{lcccc}
\hline \multirow{2}{*}{ Formas de extração } & \multicolumn{4}{c}{ Espécies bacterianas ATCC } \\
\cline { 2 - 5 } & $\begin{array}{c}\text { Staphylococcus } \\
\text { aureus }\end{array}$ & $\begin{array}{c}\text { Enterococcus } \\
\text { faecalis }\end{array}$ & $\begin{array}{c}\text { Salmonella } \\
\text { enteritidis }\end{array}$ & $\begin{array}{c}\text { Escherichia } \\
\text { coli }\end{array}$ \\
Hidroalcoolatura & $9,58^{\mathrm{b} \mathrm{A}}$ & $10,33^{\mathrm{a} \mathrm{A}}$ & $10,83^{\text {a A }}$ & $10,00^{\text {a A }}$ \\
Decocto com reconstituição & $3,87^{\mathrm{b} \mathrm{C}}$ & $6,0^{\text {a B }}$ & $2,0^{\text {c B }}$ & $2,0^{\text {c B }}$ \\
Decocto sem reconstituição & $5,5^{\text {a }}$ & $6,0^{\text {a B }}$ & $2,0^{\text {b B }}$ & $2,0^{\text {b B }}$ \\
\hline
\end{tabular}

Letras maiúsculas diferentes sobrescritas na mesma coluna indicam diferenças significativas entre os tipos de extração e letras minúsculas diferentes sobrescritas na mesma linha indicam diferenças significativas entre as espécies bacterianas para a análise de variância (Anova) e teste de Tukey $(p<0,05)$.

com a extração por hidroalcoolatura que é a frio. Oliveira et al. (2001), testando várias formas de extração em marcela para caracterizar sua ação medicinal e farmacológica, confirmaram a eficiência da extração etanólica (alcoolaturas e hidroalcoolaturas).

Em síntese, os extratos de Achyrocline satureioides ("macela", "marcela") originados das diferentes formas de extração, apresentaram capacidade de inibição ou de inativação in vitro seletivas sobre os quatro inóculos bacterianos padrões de interesse em alimentos selecionados para este trabalho, tendo a forma de extração hidroalcoólica apresentado atividade mais intensa do que as de decocção frente a estes agentes. A bactéria mais sensível a todas as formas de extração foi $E$. faecalis, seguida por $S$. aureus, ambas Gram-positivas e as menos sensíveis foram as Gram-negativas, $S$. enteritidis e E. coli para a extração por decocção tanto com como sem reconstituição.

Nas condições do experimento, os resultados permitem concluir, outrossim, que Achyrocline satureioides ("macela", "marcela"), apresenta potencialidades quanto à atividade antibacteriana com vistas a sua aplicação em ações básicas no cuidado em saúde, uma vez consideradas as formas de extração, e os próprios agentes causais envolvidos, entre outros fatores.

\section{REFERÊNCIA}

AVANCINI, C.A.M.; WIEST, J.M. Atividade desinfetante do decocto de Hypericum caprifoliatum Cham. e Schlecht. - Guttiferae (escadinha, sinapismo) frente a diferentes doses infectantes de Staphylococcus aureus (agente infeccioso em mastite bovina). Revista Brasileira de Plantas Medicinais, v.10, n.1, p.64-9, 2008.

BOSCOLO, O.H.; VALLE, L. S. Plantas de uso medicinal em Quissama, Rio de Janeiro, Brasil. IHERINGIA, v. 63, n.2, p.263-77, 2008.
CARVALHO, H.H.C. et al. Atividade antibacteriana em plantas com indicativo etnográfico condimentar em Porto Alegre, RS/Brasil. Revista Brasileira de Plantas Medicinais, v.7, n.3, p.25-32, 2005.

CARVALHO, H.H.; WIEST, J.M.; CRUZ, F.T. Atividade antibacteriana in vitro de pimentas e pimentões (Capsicum sp.) sobre quatro bactérias toxinfectivas alimentares. Revista Brasileira de Plantas Medicinais, v.12, n.1, p.8-12, 2010.

CAVALI-SFORZA, L. Biometric. Stuttgart: GustavFisher, 1974. p.201-4.

CALVO, D. et al. Achyrocline satureioides (Lam.) DC. (Marcela) : antimicrobial activity on Staphylococcus spp. And immonomodulating effects on human lymphocytes. Revista Latinoamericana de Microbiologia, v. 48, n.3-4, p. 247-55, 2006.

DEUTSCHE VETERINÄRMEDIZINISCHE GESELLSCHAFTDVG. Richtlinien zur Prüfung Chemischer Desinfektionsmittel für die Veterinämedizin. In: SCHLIESSER, T.; STRAUCH, D. Desinfektion in Tierhaltung, Fleish- und Milchwirtschaft. Stuttgart: Enke Verlag, 1981. p.47-55.

FARMACOPÉIA BRASILEIRA. 3.ed. São Paulo: Organização Andrei Editora, 1987. 1218p.

GIROLOMETTO, G. et al. Atividade antibacteriana de extratos de erva-mate (Ilex paraguaiensis A. St. Hill.). Revista Brasileira de Plantas Medicinais, v.11, n.1, p.4955, 2009.

LEMOS, G.C.S. et al. Bacterial activity of macela (Achyrocline satureioides (Lam.) DC. against strians of Sthapylococcus aureus isolated from subclinical bovine mastites. Revista Brasileira de Plantas Medicinais, v.3, n.1, p.67-72, 2000.

LORENZI, H.; MATOS, F. J. A. Plantas medicinais no Brasil: nativas e exóticas. Nova Odessa: Instituto Plantarum, 2008. 576p.

MING, L.C. Coleta de plantas medicinais. In: DI STASI, L.C. Plantas medicinais arte e ciência: um guia de estudo interdisciplinar. São Paulo: UNESP, 1996. p.69-86.

OLIVEIRA, A.L. et al. Achyrocline satureioides (LAM) DC. (marcela), Asteraceae, avaliação comparativa da droga vegetal e estudos preliminares de otimização da extração. Caderno de Farmácia, v.17, n.1, p.33-8, 2001.

PASSOS, M.G.; CARVALHO, H.; WIEST, J.M. Inibição e

Rev. Bras. PI. Med., Botucatu, v.13, n.3, p.298-304, 2011. 
inativação in vitro de diferentes métodos de extração de Ocimum gratissimum L. ("alfavacão", "alfavaca”, "alfavacacravo") - Labiatae (Lamiaceae), frente a bactérias de interesse em alimentos. Revista Brasileira de Plantas Medicinais, v.11, n.1, p.71-8, 2009.

PHILLIPSON, J.D. 50 years of medicinal plant research every progress in methodology is a progress in science. Planta Medica, v.69, n.4, p.491-5, 2003.

RATES, S.M.K. Promoção do uso racional de fitoterápicos: uma abordagem no ensino de Farmacognosia. Revista Brasileira de Farmacognosia, v.11, n.2, p.57-69, 2001. ROMEIRO, R.S. Técnica de microgota para contagem de células bacterianas viáveis em suspensão. Laboratório de bacteriologia de plantas. Viçosa: UFV. Disponível em:< http://www.ufv.br/dfp/bac/uni9.pdf>. Acesso em: 25 ago. 2008.

SCHENKEL, E.P.; GOSMANN, G.; PETROVICK, P.R. Produtos de origem vegetal e o desenvolvimento de medicamentos. In: SIMÕES, C.M.O. et al. Farmacognosia: da planta ao medicamento. 5.ed. Porto Alegre/ Florianópolis: UFRGS/UFSC, 2003. p.371-400.

SIMÕES, C.M.O. et al. Plantas da medicina popular no Rio Grande do Sul. Porto Alegre: UFRGS, 1988. p.108-9. SISVAR 5.0. Softwares Dowloads. Disponível em:<http:/ /www.dex.ufla.br/ danielff/ softwares.htm>. Acesso em: 23. set. 2007.

SOUZA, A.A.; WIEST, JM. Atividade antibacteriana de
Aloysia gratissima (Gill et Hook) Tronc. (garupa, ervasanta) usada na medicina tradicional no rio Grande do Sul-Brasil. Revista Brasileira de Plantas Medicinais, v.9, n.3, p.23-9, 2007.

VENDRUSCOLO, G.S.; RATES, S.M.K.; MENTZ, L.A. Dados químicos e farmacológicos sobre plantas utilizadas como medicinais pela Comunidade do bairro Ponta Grossa, Porto Alegre, Rio Grande do Sul. Revista Brasileira de Farmacognosia, v.15, n.4, p.360-72, 2005.

WIEST, J.M. et al. Inibição e inativação in vitro de Salmonella spp. com extratos de plantas com indicativo etnográfico medicinal ou condimentar. Arquivo Brasileiro de Medicina Veterinária e Zootecnia, v.61, n.1, p.119-27, 2009a.

WIEST, J.M. et al. Inibição e inativação de Eschirichia coli por extratos de plantas com indicativo etnográfico medicinal ou condimentar. Ciência e Tecnologia de Alimentos, v.29, n.3, p.1-7, 2009b.

WIEST, J.M. et al. Atividade anti-estafilocócica em extratos de plantas com indicativo medicinal ou condimentar. Revista Brasileira de Plantas Medicinais, v.11, n.2, p.20915, 2009c.

WU, V.C.H. A review of microbial injury and recovery methods in food. Food Microbiology, v.25, n.6, p.735-44, 2008.

ZAYACHKIVSKA, O.S. et al. Gastroprotective effects of flavonoids in plant extracts. Journal of Physiology and Pharmacology, v.56, supl. 1, p.219-31, 2005. 